\title{
Effects of silymarin (Silybum marianum) supplementation on milk and blood parameters of dairy cattle
}

\author{
I. Ulger"1", A.C. Onmaz ${ }^{2}$ \& T. Ayaşan ${ }^{3}$ \\ ${ }^{1}$ Erciyes University, Seyrani Faculty of Agriculture, Department of Animal Science, Kayseri/Turkey \\ ${ }^{2}$ Erciyes University, Faculty of Veterinary Medicine, Department of Internal Medicine, Kayseri/Turkey \\ ${ }^{3}$ East Mediterranean Agricultural Research Institute, Feeds and Animal Nutrition, Adana/Turkey
}

(Received 8 May 2017; Accepted 3 August 2017; First published online 25 September 2017)

\begin{abstract}
Copyright resides with the authors in terms of the Creative Commons Attribution 4.0 South African License.
See: http://creativecommons.org/licenses/by/4.0/za

Condition of use: The user may copy, distribute, transmit and adapt the work, but must recognize the authors and the South African Journal of Animal Science.
\end{abstract}

\begin{abstract}
The present study was conducted to investigate the effect of dietary silymarin on milk yield, milk fat, and certain blood parameters of dairy cattle. Silymarin is a naturally accepted hepatoprotectant that is used in the treatment of liver diseases in human beings, and has been tested in dairy cows during peripartum. Animals are subject to subclinical fatty liver. In the first part of the study, the silymarin $(20 \mathrm{~g} / \mathrm{head} / \mathrm{day})$ was supplemented to dairy cattle rations in the last 21 days (peripartum) of pregnancy. In the second part of study, silymarin was added to the rations of Holstein dairy cows for three weeks postpartum. A total of 40 Holstein dairy cows at $2^{\text {nd }}$ lactation with $550-600 \mathrm{~kg}$ live weight and average body condition score of 3.5 were used. Dairy cows were randomly separated into two treatment groups (20 cows in each). The first group was control (no addition) and the second group was treatment (silymarin supplemented) group. Treatments significantly increased milk yield, but decreased milk protein. Postpartum bodyweight loss was significantly less in the silymarin group than in the control group. Differences in postprandial plasma triglyceride (TRG) and total cholesterol (TC) levels were found to be significant. Plasma alanine aminotransferase (ALT) and total protein (TP) values of the groups were also significantly different. As a result, it was observed that silymarin supplementation of the ration did not have side effects, and peak milk yields could be achieved earlier with silymarin treatment. Application of silymarin is believed to be useful. It was also observed that silymarin treatments speeded up the metabolic adaptation process of the dairy cows at the beginning of lactation. It was suggested that silymarin should be used in transition periods of dairy cattle.
\end{abstract}

Keywords: Body condition score, carsil, milk thistle, milk yield, peripartum,

\#Corresponding author: i_ulger@hotmail.com

\section{Introduction}

Various metabolic problems are experienced through periparturient periods of dairy cattle. Dry matter (DM) intakes decrease during the last period of pregnancy and at the beginning of lactation. Together with negative energy balance, intense mobilization is experienced in body building scores (Drackley, 1999; Bobe et al., 2004; Oltenacu \& Broom, 2010). The energy balance of high-yield cows is disrupted when the required energy is not supplied with their rations. Then, as a result of maladaptation to this negative energy balance, hepatic lipidosis (fatty liver) and ketosis-like metabolic diseases occur (Herdt, 2000; Mann et al., 2015).

While the survival rate energy requirements of animals with different milk yields are the same, yield rate requirements may be different. This difference points out the significance of energy balance being provided through feeding in high-yield animals (Capper et al., 2008). In hepatic lipidosis cases, non-esterified fatty acid quantities increase and they are esterified to triglyceride through oxidation of hepatic fatty acids. Hepatic lipidosis increases the risk of ketosis, abomasum displacement, metritis, and immune system suppression, and reduces reproductive performance (Bobe et al., 2004). During the peripartum period, in addition to reduced dry matter intake and negative energy balance, intense metabolization of body building stones is experienced. In that period, hepatoprotective agents are used to prevent fat accumulation in the liver. Methionine, choline, propylene glycol, and glycerol were used as preservatives in the cattle during the studies and their therapeutic properties were discovered (MoaUem et al., 2007; Grummer,1993; Bertics \& Grummer, 1999; Goff et al.,1996). Silymarin is a hepatoprotective agent that contains liver-protecting substances. It is a standard extract that is taken from Silybum marianum $L$. (milk thistle) seeds and is used in the treatment of human liver diseases with various aetiologies (Saller et al., 2001). Silymarin extract is a 
complex structure composed of several flavonolignan isomers (Skottova et al., 2003). Silymarin has been used in herbal treatments for 2000 years.

Today, it is commonly used in the protection and treatment of the liver (Morazzoni \& Bombardelli, 1995; Tamayo \& Diamond, 2007). Improvements and increased functionality were observed in damaged livers with silymarin treatments (Leng, 1996; Fraschini et al., 2002). Silymarin influences cell permeability and has an antioxidant characteristic that prevents lipid peroxidation and membrane breakdown (Muriel \& Mourelle, 1990; Mira et al., 1994; Fuchs et al., 1997). Such impacts of silymarin were reported by other researchers (Campose et al., 1989; Muriel \& Mourelle, 1990; Mira et al., 1994). Skottova et al. (2003) reported that the polyphenol fraction of silymarin had positive effects on the lipoprotein profile of plasma and prevented fatty liver development in rats. Silymarin also significantly reduced serum gamma glutamyltranspeptidase, alanine transaminase (AST) and the aspartate transaminase levels of rats with liver damage (Wang et al., 1996).

The present study was therefore conducted to investigate the effects of silymarin supplementation to dairy cattle rations in preventing negative energy balance-induced liver damage on serum blood parameters [calcium (Ca), glucose (GL), triglyceride (TRG), cholesterol (TC), phosphorus (P), ALT and AST, total protein (TP)], milk yield, and components of fat, protein, lactose.

\section{Materials and Methods}

A commercial dairy herd with 1700 lactating Holstein Friesian dairy cows located in Kayseri Province, Turkey, was used. The herd was housed in a free-stall barn, fed on total mixed rations (TMR), and milked twice daily. Silymarin was supplemented to rations of second parity Holstein dairy cows with three weeks to calving. In the second part of study, silymarin was added to the rations of Holstein dairy cows for three weeks postpartum. The cows had live weights between 555 and $600 \mathrm{~kg}$. The cows were selected from those with an average body condition score (BCS) of 3.5. Two groups were formed with 20 cows each (a total of 40 dairy cows were used). The first group was fed a regular ration (control). Together with the regular ration, silymarin extract was supplied to the second group orally, immediately after mixing with water to have 20 $\mathrm{g} / \mathrm{head} /$ day silymarin consumption.

Animal feeds were supplied based on DM intake to have $20.77 \mathrm{~kg}$ feed per animal. Rations were prepared in accordance with the norms specified by National Research Council (NRC, 2001) for Holstein breed dairy cows with an average daily milk yield of 35 litres to meet their daily nutritional needs. Nutritional and chemical composition of the feeds supplied to animals are provided in Table 1 and the components of concentrate feed are listed in Table 2. The chemical composition of concentrate feed is provided in Table 3.

Table1 Components and chemical composition of TMR

\begin{tabular}{|c|c|c|c|c|}
\hline Ingredients & & Naturally/kg & DM kg & Ration DM\% \\
\hline Corn silage & & 13.00 & 4.02 & 19.34 \\
\hline Wheat straw & & 2.70 & 2.57 & 12.38 \\
\hline Dry alfalfa & & 1.50 & 1.38 & 6.65 \\
\hline Beet pulp & & 1.00 & 0.19 & 0.91 \\
\hline Cattle milk feed (concentrated feed) & & 13.50 & 12.61 & 60.73 \\
\hline Parameters & Dry alfalfa & Corn silage & Beet pulp & Wheat straw \\
\hline $\mathrm{CP} \%$ & 25.10 & 8.93 & 11.00 & 4.96 \\
\hline $\mathrm{CA} \%$ & 9.08 & 4.28 & 4.48 & 7.56 \\
\hline DM\% & 92.00 & 30.90 & 18.80 & 95.20 \\
\hline $\mathrm{CC} \%$ & 1.98 & 3.22 & 2.00 & 1.63 \\
\hline ADF\% & 28.60 & 28.00 & 23.30 & 49.10 \\
\hline NDF\% & 39.20 & 45.20 & 45.50 & 73.20 \\
\hline ME (Mcal/kg) & 2.040 & 2.320 & 2.65 & 1.52 \\
\hline
\end{tabular}

Naturally (added to the ration), CP: crude protein (\%of DM), CA: crude ash (\% of DM), DM: dry matter (\% of fresh), crude fat $(\%$ of DM), ADF: acid detergent fibre (\% of DM), NDF: neutral detergent fibre (\% of DM), ME: metabolizable energy (Mcal/kg DM) 
Table 2 Components of concentrate feed supplied to animals

\begin{tabular}{lccc}
\hline Concentrated feed components & Naturally, kg & DM, kg & Ration DM\% \\
\hline Grain barley & 2.73 & 2.67 & 22.06 \\
Soybean meal (46\% CP) & 3.48 & 3.24 & 27.00 \\
Soybean full-fat & 0.65 & 0.6 & 5.00 \\
Kernel corn & 1.56 & 1.48 & 12.23 \\
Kernel wheat & 0.65 & 0.61 & 5.04 \\
Corn bran & 0.32 & 0.30 & 2.47 \\
Wheat bran & 0.65 & 0.60 & 5.00 \\
Molasses & 0.45 & 0.39 & 3.22 \\
Cottonseed meal (30\% CP) & 0.26 & 0.24 & 2.00 \\
Bypass oil & 0.32 & 0.31 & 2.56 \\
Marble powder & 0.27 & 0.27 & 2.23 \\
Sunflower seed meal (37\% CP) & 1.17 & 1.10 & 9.09 \\
Salt & 0.23 & 0.21 & 1.73 \\
DCP (dicalcium phosphate) & 0.07 & 0.07 & 0.06 \\
Premixed* & 0.01 & 0.01 & 0.08 \\
\hline Naturally (added to the ration): vitamin-mineral premixed two kg of eating a ton. Mineral and vitamin content: vitamin A \\
12,000,000 Ul; vitamin D3 2,400,000 Ul; vitamin E 50000 mg; vitamin K3 1000 mg; vitamin B1 600 mg; vitamin B2 2500 \\
mg; vitamin B6 150 mg; vitamin C 2000 mg; niacin 200000 mg; folic acid 2000 mg; biotin 200 mg; choline chloride \\
100000mg; d I methionine 330 mg; iron 80000 mg; copper 15000 mg; manganese 50000 mg; cobalt 150 mg; zinc \\
150000 mg; iodine 800 mg; selenium 150 mg & &
\end{tabular}

Table 3 Nutrient composition of concentrate feed (milk feed) (DM basis)

\begin{tabular}{lcc}
\hline Nutrients & $\begin{array}{c}\text { Calculated results } \\
\text { (Declaration of manufacturer) }\end{array}$ & Analysed results \\
\hline $\mathrm{CP} \%$ & 22 & 22.45 \\
$\mathrm{DM} \%$ & 88 & 93.42 \\
$\mathrm{CA} \%$ & 8 & 8.22 \\
$\mathrm{CS} \%$ & 12 & 8.74 \\
$\mathrm{CF} \%$ & - & 3.64 \\
$\mathrm{ME}$ & 2750 & 2785 \\
\hline
\end{tabular}

CP: crude protein (\%of DM), DM: dry matter (\% of fresh), CA: crude ash (\% of DM), CC: crude cellulose (\% of DM), CF: crude fat (\% of DM), ME: metabolizable energy (Mcal $/ \mathrm{kg}$ DM)

Analyses of DM, CA, CP, CC, and CF contents of feed sources were carried out in accordance with AOAC (1998). Acid detergent fibre (ADF) and neutral detergent fibre (NDF) analyses were carried out in accordance with Van Soest et al. (1991), and metabolic energy (ME) was calculated by the equation proposed by Robinson et al. (2004):

$$
\mathrm{ME}=14.03-(0.01386 \times \mathrm{CF} \%)-(0.1018 \times \mathrm{CA} \%) .
$$
$500 \mathrm{~g})$

From the beginning of the experiment, bodyweights were measured weekly with a digital balance $( \pm$

Daily milk yields of each animal were recorded to a herd management programme separately from the Dairymaster milking system. Then, milk yield per animal was taken from the system. A total of 40 milk samples were taken and subjected to Foss MilkoScan FT1 device (Milkoscan, Foss, Denmark) without waiting for chemical analysis.

At the beginning and end of the study, 80 blood samples were taken from the vena jugularis four hours after feeding. The blood samples were placed $10 \mathrm{ml}$ tubes containing heparin, and centrifuged at $3000 \mathrm{rpm}$ 
for 10 minutes to obtain blood plasma. The resultant plasma samples were kept in a deep freezer at $-20^{\circ} \mathrm{C}$ until the time of analysis.

Plasma samples were then thawed at room temperature and subjected to ALT, AST, TP, glucose, triglyceride, and cholesterol analyses at the central laboratories of Erciyes University Medical Faculty. For metabolite analysis of the plasma samples, an autoanalyser with commercial kits (Abbott Diagnostics, Architect, USA) was used.

The following mathematical model was used in experiments:

$$
Y_{i j}=\mu+\alpha_{i}+\varepsilon_{i j}
$$

Where: $Y_{i j}=$ observation value for $j^{\text {th }}$ replication of $i^{\text {th }}$ treatment

$\mu=$ general population mean

$\alpha_{i}=$ effect of $i^{\text {th }}$ treatment

$e_{i j}=$ random error for $j^{\text {th }}$ replication of $i^{\text {th }}$ treatment

Significance level was set as $P<0.05$. Results were expressed as mean \pm standard error. All analyses were carried out with the GLM module of SAS software.

\section{Results}

The differences in prenatal and postnatal first-week bodyweights were not found to be significant (Table 4). However, bodyweights of the groups were significant in the second and third week $(P<0.05)$.

Table 4 Body weights at the beginning and the end of experiment and milk components

\begin{tabular}{lcccc}
\hline Parameters & Control & Silymarin & SEM & P \\
\hline Prenatal BW & 564.15 & 564.95 & 2.624 & 0.881 \\
First week BW & 518.85 & 519.95 & 2.426 & 0.824 \\
Second week BW & 493.00 & 514.55 & 2.901 & $<0.001$ \\
Third week BW & 488.00 & 514.55 & 3.142 & $<0.001$ \\
\hline Milk yield,\% & 27.30 & 30.50 & 0.492 & $<0.001$ \\
Milk fat,\% & 3.54 & 3.46 & 0.013 & 0.003 \\
Milk protein,\% & 3.72 & 3.45 & 0.027 & $<0.001$ \\
Milk lactose,\% & 4.94 & 4.94 & 0.013 & 0.939 \\
\hline
\end{tabular}

SEM: standard error of mean; P: probability; BW: bodyweight $(\mathrm{kg})$

There was less postnatal weight loss in the silymarin treated cows than the control group. There were significant differences in the milk yields of the control and the treatment group $(P<0.001)$. The silymarin group had higher milk yield than the control group. On the other hand, milk fat and protein contents were higher in the control group than in the treatment group. The differences in milk fat and protein contents were found to be significant, but the differences in milk lactose contents were not $(P=0.939)$.

The values obtained from the blood samples in the initial stage of the study are provided in Table 5. The differences among the blood parameters of the groups were not found to be significant.

Compared with prenatal blood samples, the glucose concentration of postnatal samples decreased. This decrease was lower in the silymarin group. The differences in plasma glucose contents of the groups were not found to be significant $(P=0.036)$. While there were significant differences in the concentrations of plasma TRG $(P=1.000)$ and plasma cholesterol $(P=0.680)$, the silymarin group had higher TRG and cholesterol concentrations than the control treatment. However, it was not statistically significant. While the effects of silymarin treatments on AST enzyme activity were not significant $(P=0.416),(P=0.397)$, increasing ALT enzyme activities were observed with silymarin treatments $(P<0.001)$. The prenatal treatment group had lower protein concentrations than the control group, but these differences were not found to be significant $(P=0.085)$. However, postnatal plasma protein concentrations were higher in the treated group $(P<0.001)$. The differences in prenatal $\mathrm{Ca}$ and $\mathrm{P}$ concentrations of plasma samples of the silymarin group were not significant. On the other hand, lower decreases were observed in the $\mathrm{Ca}$ and $\mathrm{P}$ 
concentrations of postnatal plasma samples of the treatment group, but the differences were not found to be significant $(P=0.844),(P=0.283)$.

Table 5 Biochemical blood parameters of experimental cows at the beginning and end of experiment

\begin{tabular}{|c|c|c|c|c|}
\hline \multirow{2}{*}{ Parameters } & \multicolumn{2}{|c|}{ Prenatal } & \multirow{2}{*}{ SEM } & \multirow{2}{*}{$\mathbf{P}$} \\
\hline & Control & Silymarin & & \\
\hline $\mathrm{GL}(\mathrm{mg} / \mathrm{dL})$ & 53.40 & 46.65 & 1.627 & 0.036 \\
\hline TRG (mg/dL) & 31.65 & 31.65 & 0.533 & 1.000 \\
\hline $\mathrm{TC}(\mathrm{mg} / \mathrm{dL})$ & 101.55 & 99.65 & 2.264 & 0.680 \\
\hline AST (U/I) & 63.25 & 60.15 & 1.878 & 0.416 \\
\hline ALT (U/I) & 27.45 & 28.00 & 1.013 & 0.790 \\
\hline TP (mg/dL) & 7.51 & 7.11 & 0.117 & 0.085 \\
\hline $\mathrm{Ca}(\mathrm{mg} / \mathrm{dL})$ & 14.75 & 13.55 & 1.274 & 0.644 \\
\hline $\mathrm{P}(\mathrm{mg} / \mathrm{dL})$ & 7.33 & 6.80 & 0.614 & 0.675 \\
\hline \multirow{2}{*}{ Parameters } & \multicolumn{2}{|c|}{ Postnatal } & SEM & P \\
\hline & Control & Silymarin & SEMI & $\mathbf{P}$ \\
\hline $\mathrm{GL}(\mathrm{mg} / \mathrm{dL})$ & 41.15 & 45.65 & 1.236 & 0.068 \\
\hline TRG (mg/dL) & 14.15 & 26.65 & 1.100 & $<0.001$ \\
\hline $\mathrm{TC}(\mathrm{mg} / \mathrm{dL})$ & 78.55 & 98.15 & 2.333 & $<0.001$ \\
\hline AST (U/I) & 59.75 & 56.50 & 1.890 & 0.397 \\
\hline $\operatorname{ALT}(\mathrm{U} / \mathrm{I})$ & 30.45 & 38.00 & 1.179 & $<0.001$ \\
\hline $\mathrm{TP}(\mathrm{mg} / \mathrm{dL})$ & 6.26 & 7.11 & 0.132 & $<0.001$ \\
\hline $\mathrm{Ca}(\mathrm{mg} / \mathrm{dL})$ & 12.65 & 13.15 & 1.244 & 0.844 \\
\hline $\mathrm{P}(\mathrm{mg} / \mathrm{dL})$ & 5.25 & 6.60 & 0.622 & 0.283 \\
\hline
\end{tabular}

SEM: standard error of means; P: probability; GL: glucose (mg/dL); TRG: triglyceride (mg/dL); TC: total cholesterol (mg/dL); AST: aspartate amino transferase enzyme (U/l); ALT: alanine amino transferase enzyme (U/l); TP: total protein (g/dL); Ca: calcium (mg/dL); P: phosphorus (mg/dL)

\section{Discussion}

Experiments were conducted in two phases, namely prenatal and postnatal. In comparison with the control treatment, bodyweight, milk yield, differences in parameters were observed in serum blood TRG, TC, ALT, AST, and TP. There were no problems with regard to health of animals in both prenatal and postnatal periods. Bodyweight losses were higher in the control group than in the treatment group (Gerloff et al., 1986). Body weight measurements at the end of the third week revealed that weight loss was higher in the control group than in treatment group. Previous studies also reported body weight losses in early lactation period (Ingvartsen et al., 2003; Meijer, 2010). However, weight loss was lower in the silymarin-treated group.

Higher weight losses in the control group than the treatment group could be related to hepatic lipidosis and resultant malfunction of the liver (Gerloff et al., 1986). Lucy et al. (2001) indicated that total milk yield could be improved with proper feeding throughout the transition period. Silymarin reduced the negative conditions experienced in transition to metabolic adaptation at the beginning of lactation and thus improved the milk yields. Although there are not any concrete evidences that silymarin treatments improved milk yields, similar findings were reported in previous studies (Garavaglia et al., 2015). Besides antioxidant impacts, silymarin was reported to have hepatoprotective effects, and to prevent fat accumulation in the liver (Tedesco et al., 2004). In terms of the plasma glucose levels, significant differences were not observed between prenatal and postnatal values. The decrease in plasma glucose levels was lower in silymarin group than in control group.

The decrease in insulin concentration might have resulted in reduced serum glucose concentration. With silymarin treatments, plasma insulin concentration may increase fatty acid oxidation in the pancreas. Stimulation of insulin segregation from pancreas $\beta$-cells by glucose depends on the availability of fatty acids (Stein et al., 1996). Fatty acid oxidation in $\beta$-cells may increase in cows fed with silymarin-supplemented 
rations and reduced availability of fatty acids may cause an increase in insulin segregation. On the other hand, silymarin supplementation may alter peripheral glucose metabolism and insulin sensitivity, and thus influence glucose metabolism. It was observed that silymarin influenced not only $\beta$-oxidation of fatty acids, but also glucose metabolism. Silymarin treatments increased glucose oxidation and storage in patients with type II diabetes (Mingrona et al., 1999; Tedesco et al., 2004). Present plasma glucose quantities comply with those of earlier reports (Mehta \& Gangwar, 1985; Karagül et al., 1999; Polat et al., 2002).

It has been reported in previous studies that silymarin reduces triglyceride synthesis in liver (Skottova \& Kreeman, 1998) and activates fatty acid $\beta$-oxidation (Valenzuela \& Garrido, 1994). However, in another study, less reduction was reported in the TRG quantities of the silymarin group than the control group. Current plasma triglyceride levels do not comply with those of earlier reports (Mourelle et al., 1989; Valenzuela \& Garrido, 1994; Skottova \& Kreeman, 1998).

Although there were no significant differences in TC and TRG concentrations, there was a numerical decrease in TC concentrations of treatment group than the control.

Plasma cholesterol levels were similar to earlier findings (Haddad et al., 2011). Haddad et al. (2011) reported that silibinin extracts $(200 \mathrm{ml} / \mathrm{kg})$ in a high-fat liquid diet decreased the cholesterol levels of rats, but the differences were not significant. Sobolova et al. (2006) reported increased serum cholesterol levels of rats with silymarin extract treatments. In another similar study, silymarin significantly reduced liver cholesterol levels (Skottova et al., 2003; Sobolova et al., 2006). The ALT and AST exhibit quite high activity in acute or chronic liver damage, and such activity can be identified in serum (Turgut, 2000). Fatty liver syndrome in lactating cows may reduce the appetite (Cebra et al., 1997), and ketosis at early lactation may increase AST enzyme activity (Steen, 2001). This may be used as a bio-indicator for possible liver damage (Kauppinen, 1984; Meyer \& Harvey, 1988). Contrary to AST activity, ruminants do not have high ALT activity. Changes in serum ALT activities thus cannot be clearly identified in liver damage (Forenbacher, 1993). There are distinctive irregular and slight changes in AST and gamma glutamyl transferase enzyme activities in pregnancy and early lactation periods. On the other hand, ALT activities decrease distinctively during the seventh and eighth months of pregnancy and at the beginning of lactation (Tainturier et al., 1984). In the present study, differences in AST activities of treatment and control group were not found to be significant. The decrease in AST activity may be related to silymarin supplementation. As indicated, an increase in serum AST activity may be used for sub-clinic diagnosis of possible liver damage (Kauppinen, 1984; Meyer \& Harvey, 1988). Therefore, different silymarin levels may be experimented with for various periods to elucidate these effects. The present findings may also provide significant contributions for researchers that are studying the protective effects of silymarin on liver. In the present study, significant differences were observed only in postnatal ALT activities. These differences had resulted from transition from feed adaptation to lactation periods. Stojević et al. (2005), reported significant increases in serum ALT activities in early lactation compared with the control treatment. In the present study, silymarin supplementation increased ALT activities, but such changes were not considered sufficient to be related to liver damage.

\section{Conclusion}

It was concluded that silymarin supplementation to feed rations did not have negative side effects. It was also observed that silymarin supplementations might speed up the transition to metabolic adaptation of dairy cows at the beginning of lactation, and might result in earlier achievement of peak milk yield. Various silymarin doses could be applied to observe the impacts of silymarin supplementation on tissues, especially on liver. In further studies, the effects of silymarin treatments on the metabolic profile could be studied in detail. The present findings might contribute to those future studies on silymarin supplementation.

\section{Acknowledgements}

The authors would like to thank the Pandoga Farm Management (Kayseri, Turkey) and Mr. Ekrem Kaygısız for providing animals and technical help during the experiment.

\section{Authors' Contributions}

IÜ designed the project, collected the data and did the statistical analysis. ACO did the laboratory analysis. TA wrote and edited the manuscript until it was submitted to the journal to be considered for publication.

\section{Conflict of Interest Declaration}

The authors declare that there is no conflict of interest.

\section{References}

AOAC, 1998. Official methods of analysis. Association of Official Analytical Chemists, Arlington, Virginia, USA

Bertics, S.J. \& Grummer, R.R., 1999. Effects of fat and methionine hydroxy analog on prevention or alleviation of fatty liver induced by feed restriction. J. Dairy Sci. 82, 2731-2736. 
Bobe, G., Young, J.W. \& Beitz, D.C., 2004. Pathology, etiology, prevention, and treatment of fatty liver in dairy cows. J Dairy Sci. 87, 3105-3124.

Campos, R., Garrido, A., Guerra, R. \& Valenzuela, A., 1989. Silybin dihemisuccinate protects against glutathione depletion and lipid peroxidation induced by acetaminophen on rat liver. Planta Med. 55, 417-419.

Capper, J.L., Cady, R.A. \& Bauman, D.E., 2008. Increased production reduces the dairy industry's environmental impact. In: Proceedings of the Cornell Nutrition Conference, 2008, p55-66.

Cebra, C.K., Gerry, F.B., Getzy, D.M. \& Fettman, M.J., 1997. Hepatic lipidosis in anorectic, lactating Holstein cattle: Retrospective study of serum biochemical abnormalities. J. Vet. Int. Med. 4, 231-237.

Drackley, J.K., 1999. Biology of dairy cows during the transition period: The final frontier? J. Dairy Sci. 82, $2259-2273$.

Fraschini, F., Demartini, G. \& Esposti, D., 2002. Pharmacology of silymarin. Clin. Drug Investig. 22, 51-65.

Forenbacher, S., 1983. Klinicka patologija probave i mijene tvari domacih zivotinja. Svezak 1/2 Klinicka patologija probave i resorpcije, Zagreb, Croatia.

Fuchs, E.C., Weyhenmeyer, R. \& Weiner, O.H., 1997. Effects of silibinin and of a synthetic analogue on isolated rat hepatic stellate cells and myofibroblasts. Arzneimittel-Forschung. 47, 1383-1387.

Haddad, Y., Vallerand, D., Brault, A. \& Haddad, P.S., 2011. Antioxidant and hepatoprotective effects of silibinin in a rat model of nonalcoholic steatohepatitis. Evidence-based complementary and alternative medicine. Oxford University Press, Oxford, 35,8-115.

Herdt, T.H., 2000. Ruminant adaptation to negative energy balance: Influences on the etiology of ketosis and fatty liver. Vet. Clin. North Am. Food Anim. Pract. 16, 215-230.

Garavaglia, L., Galletti, S. \& Tedesco, D., 2015. Silymarin and lycopene administration in periparturient dairy cows: Effects on milk production and oxidative status. N Z Vet. J. 63, 313-318.

Gerloff, B.J., Herdt, T. \& Emery, R.S., 1986. Relationship of hepatic lipidosis to health and performance in dairy cattle. J. American Vet. Med. Ass. 188, 845-850.

Goff, J.P., Horst, R.L., Jardon, P.W., Borelli, C. \& Wedam, J., 1996. Field trials of an oral calcium propionate paste as an aid to prevent milk fever in periparturient dairy cows. J. Dairy Sci. 79, 378-383.

Grummer, R.R. 1993. Etiology of lipid-related metabolic disorders in periparturient dairy cows. J. Dairy Sci. 76, $3882-$ 3896.

Ingvartsen, K.L., Dewhurst, R.J. \& Friggens, N.C., 2003. On the relationship between lactational performance and health: Is it yield or metabolic imbalance that causes production diseases in dairy cattle? A position paper. Livest. Prod. Sci. 83, 277-308.

Karagül, H., Altıntaş, A., Fidancı, U.R. \& Sel, T., 1999.Temel Biyokimya Uygulamaları. Birinci Baskı. Medisan yayıneviAnkara, 187-188, 1999.

Kauppinen, K., 1984. ALAT, AP, ASAT, GGT, OCT activities and urea and total bilirubin concentrations in plasma of normal and ketotic dairy cows. Transbound. Emerg. Dis. 31, 567-576.

Leng-Peschlow, E., 1996. Properties and medical use of flavonolignans (silymarin) from Silybum marianum. Phytother. Res. 10, 25-26.

Lucy, M.C., Jiang, H., \& Kobayashi, Y., 2001. Changes in the somatotrophic axis associated with the initiation of lactation. J. Dairy Sci. 84, 113-119.

Mann, S., Yepes, F.L., Overton, T.R., Wakshlag, J.J., Lock, A.L., Ryan, C.M. \& Nydam, D.V., 2015. Dry period plane of energy: Effects on feed intake, energy balance, milk production, and composition in transition dairy cows. J. Dairy Sci. 98, 3366-3382.

Mehta, S.N. \& Gangwar, P.C., 1985. Effect of seasons on the concentration of blood plasma cholesterol and free fatty acids in lactating buffaloes (Bubalusbubalis). Indian J. Anim. Sci. (India).

Meijer, R. \& Peeters, K., 2010. The use of precision dairy farming in feeding and nutrition. In: Proceedings of The First North American Conference on Precision Dairy Management, 20-23 March 2010, Toronto.

Meyer, D.J. \& Harvey, J.W.,1998. Evaluation of hepatobiliary system and skeletal muscle and lipid disorders. In: Veterinary laboratory medicine. Interpretation and diagnosis WB Saunders, Philadelphia and London, 157-186.

Mingrone, G., Greco, A.V., Capristo, E., Benedetti, G., Giancaterini, A., Gaetano, A.D. \& Gasbarrini, G., 1999. L-karnitin improves glucose disposal in type 2 diabetic patients. J. Am. Coll. Nutr. 18, 77-82.

Mira, L., Silva, M. \& Manso, C. F.,1994. Scavenging of reactive oxygen species by silibinin dihemisuccinate. Biochem. Pharmacol. 48, 753-759.

Moallem, U., Katz, M., Arieli, A. \& Lehrer, H., 2007. Effects of peripartum propylene glycol or fats differing in fatty acid profiles on feed intake, production, and plasma metabolites in dairy cows. J. Dairy Sci. 90(8), 3846-3856.

Morazzoni, P. \& Bombardelli, E., 1995. Silybum marianum (Carduusmarianus). Fitoterapia, 66, 3-42.

Muriel, P. \& Mourelle, M., 1990. Prevention by silymarin of membrane alterations in acute CCI4 liver damage. J. Appl. Toxicol. 10, 275-279.

National Research Council (NRC), 2001. Nutrient requirements of dairy cattle. 7th rev. ed. National Academy of Science, Washington, DC.

Oltenacu, P.A. \& Broom, D.M., 2010. The impact of genetic selection for increased milk yield on the welfare of dairy cows. Anim. Welf. 19, 39-49.

Polat, Ü., Çetin, M. \& Yalçın, A., 2002. Yüksek Verimli Süt İneklerinde Laktasyonun Çeşitli Evrelerinde Kandaki Bazı Biyokimyasal Parametreler İle Süt Verimi Arasındaki İlişkiler. Uludag Univ. J. Fac. Vet. Med., 21, 65-69.

Robinson, P.H., Givens, D.I. \& Getachew, G., 2004. Evaluation of NRC, UC Davis and ADAS approaches to estimate the metabolizable energy values of feeds at maintenance energy intake from equations utilizing chemical assays and in vitro determinations. Ani. F. Sci. and Tech. 114, 75-90.

Saller, R., Meier, R. \& Brignoli, R., 2001. The use of silymarin in the treatment of liver diseases. Drugs 61, 2035-2063. 
Skottova, N., Vecera, R., Urbanek, K., Vana, P., Walterova, D. \& Cvak, L., 2003. Effects of polyphenolic fractions of silymarin on lipoprotein profile in rats fed cholesterol-rich diets. Pharmacol. Res. 47,17-26.

Sobolova, L., Skottova, N., Vecera, R. \& Urbanek, K., 2006. Effect of silymarin and its polyphenolic fraction on cholesterol absorption in rats. Pharmacol. Res. 53, 104-112.

Steen, A., 2001. Field study of dairy cows with reduced appetite in early lactation: Clinical examinations, blood and rumen fluid analyses. Acta Vet. Scand. 42, 219-228.

Stein, D.T., Esser, V., Stevenson, B.E., Lane, K.E., Whiteside, J.H., Daniels, M.B., Chen, S. \& McGarry, J.D., 1996. Essentiality of circulating fatty acids for glucose-stimulated insulin secretion in the fasted rat. J. Clin. Invest. 97, 2728-2735

Stojević, Z., Piršljin, J., Milinković-Tur, S., Zdelar-Tuk, M. \& Ljubić, B.B., 2005. Activities of AST, ALT and GGT in clinically healthy dairy cows during lactation and in the dry period. Vet. Arh. 75, 67-73.

Tainturier, D., Braun, J.P., Rico, A.G. \& Thouvenot, J.P., 1984. Variations in blood composition in dairy cows during pregnancy and after calving. Res. Vet. Sci. 37(2), 129-131.

Tamayo, C. \& Diamond, S., 2007. Review of clinical trials evaluating safety and efficacy of milk thistle (Silybum marianum L. Gaertn.). Integr. Cancer Ther. 6, 146-157.

Tedesco, D., Tava, A., Galletti, S., Tameni, M., Varisco, G., Costa, A. \& Steidler, S., 2004. Effects of silymarin, a natural hepatoprotector, in periparturient dairy cows. J. Dairy Sci., 87, 2239-2247.

Turgut, K., 2000. Veteriner klinik laboratuar teşhis. 2. Baskı, 275, Bahçıvanlar Basım Sanayi A.Ş., Türkiye.

Valenzuela, A., Lagos, C., Schmidt, K. \& Videla, L.A.,1985. Silymarin protection against hepatic lipid peroxidation induced by acute ethanol intoxication in the rat. Biochem. Pharmacol. 34, 2209-2212.

Van Soest, P.J., Robertson, J.B. \& Lewis, B.A., 1991. Methods for dietary fiber, neutral detergent fiber, and nonstarch polysaccharides in relation to animal nutrition. J. Dairy Sci. 74, 3583-3597.

Wang, M., Grange, L., Tao, J. \& Reyes, E., 1996. Hepatoprotective properties of Silybum marianum herbal preparation on ethanol induced liver damage. Fitoterapia 67,166-171. 